\title{
Biochemical studies in Tanzanian patients with ataxic tropical neuropathy
}

\author{
W. J. MAKENE AND J. WILSON ${ }^{1}$ \\ From the Faculty of Medicine, University College, Dar Es Salaam, Tanzania, \\ and the M.R.C. Clinical Genetics Research Unit, Institute of Child Health \\ and Institute of Neurology, London
}

SUMMARY Data on thiocyanate and vitamin $B_{12}$ concentrations in plasma from Tanzanian patients with ataxic tropical neuropathy are presented and support the hypothesis that, as in Nigeria, the condition may result from chronic exposure to cyanide or cyanogens from a diet including large amounts of cassava.

In a series of reports describing clinical, epidemiological, and biochemical studies from W. Nigeria (Monekosso and Wilson, 1966; Osuntokun, 1968; Osuntokun, Durowoju, McFarlane, and Wilson, 1968; Osuntokun, Monekosso, and Wilson, 1969), it has been suggested that the occurrence in that country of a diffuse neurological disease which includes optic atrophy and sensory ataxia is related to the chronic toxicity of cassava, the main food for large numbers of people living in tropical and subtropical regions.

Biochemical evidence favours the hypothesis that the neurological disease may be the result of chronic exposure either to free cyanide or to its natural precursors, and further evidence has been sought by studying similarly affected patients in Tanzania, where a similar syndrome has been described (Haddock, Ebrahim, and Kapur, 1962).

\section{PATIENTS AND METHODS}

The majority of patients were adults attending the outpatient department of Muhimbili Hospital, Dar Es Salaam, and were all seen by one of us (W.J.M.). The criteria used for diagnosis of ataxic neuropathy were the same as those used in the Nigerian studies mentioned above - that is, sensory ataxia with or without signs of pyramidal dysfunction in upper or lower limbs, and optic atrophy. It is acknowledged that, although these criteria may be imprecise and give no idea of the underlying pathological process, they coexist with sufficient frequency both in

\footnotetext{
1 Requests for reprints: J. Wilson, M.R.C. Clinical Genetics Research
} Unit, National Hospital, Queen Square, London WC1N 3BG.
Nigeria and in Tanzania to represent a distinct syndrome.

Control subjects were selected from patients suffering from other organic diseases (neurological and non-neurological) and from psychiatric disorders, and blood was obtained either as outpatients or within 48 hours of admission to hospital.

Plasma from heparinized samples of venous blood was separated within one hour of collection and stored at $-20^{\circ} \mathrm{C}$ until sufficient samples had accumulated within two months to transfer them packed in crushed ice and water in a vacuum flask by air to London.

Thiocyanate was determined by the method of Aldridge (1945) in plasma deproteinized with $10 \%$ trichloroacetic acid.

Plasma vitamin $\mathbf{B}_{12}$ was estimated with Lactobacillus leichmannii (Matthews, 1962) on divided samples. As in the study of Monekosso and Wilson (1966), one aliquot was assayed after extraction with buffer containing cyanide (total vitamin $\mathrm{B}_{12}$ ) and the other after extraction without added cyanide.

\section{RESULTS}

Mean plasma thiocyanate concentrations in patients and controls are shown in Table 1 . Levels in the patients with neurological diseases are significantly higher than in both groups of controls $(P<0.001)$ and are similar to the values found in the Nigerian studies. The levels in controls are also similar in both series.

Mean plasma vitamin $\mathbf{B}_{12}$ levels are shown in Table 2. The differences in $B_{12}$ concentrations obtained both with $\left(\mathrm{B}_{12}+\mathrm{CN}\right)$ and without $\left(\mathrm{B}_{12}-\mathrm{CN}\right)$ added cyanide during extraction are higher at the $5 \%$ level of significance in the 
TABLE 1

MEAN PLASMA THIOCYANATE CONCENTRATIONS IN PATIENTS WITH ATAXIC NEUROPATHY, AND IN CONTROLS WITH MISCELlaNeOUS DISEASES, AND WITH PSYCHIATRIC DISORDERS

\begin{tabular}{ccc}
\hline \multicolumn{3}{c}{ Patients with: } \\
\hline $\begin{array}{c}\text { Ataxic } \\
\text { neuropathy } \\
(n=8)\end{array}$ & $\begin{array}{c}\text { Miscellaneous } \\
\text { diseases } \\
(n=9)\end{array}$ & $\begin{array}{c}\text { Psychiatric } \\
\text { disorders } \\
(n=10)\end{array}$ \\
\hline $9 \cdot 3 \pm 1.9$ & $2.8 \pm 0.82$ & $1.5 \pm 0.14$ \\
\hline
\end{tabular}

Mean in $\mu$-mole $/ 100 \mathrm{ml}$, with numbers of patients, and SEM

TABLE 2

MEAN PLASMA VITAMIN B 12 CONCENTRATIONS IN PATIENTS AND IN CONTROLS, WITH AND WITHOUT CYANIDE EXTRACTION (B $B_{12}+\mathrm{CN}$, AND $B_{12}-$ CN RESPECTIVELY) AND $B_{12}-C N$ EXPRESSED AS PERCENTAGE OF $\mathrm{B}_{12}+\mathrm{CN}$

\begin{tabular}{|c|c|c|c|}
\hline & \multicolumn{3}{|c|}{ Patients with: } \\
\hline & $\begin{array}{c}\text { Ataxic } \\
\text { neuropathy } \\
n=8\end{array}$ & $\begin{array}{c}\text { Miscellaneous } \\
\text { diseases } \\
n=9\end{array}$ & $\begin{array}{c}\text { Psychiatric } \\
\text { disorders } \\
n=10\end{array}$ \\
\hline $\begin{array}{l}\mathrm{B}_{12}+\mathrm{CN} \\
\mathrm{B}_{12}-\mathrm{CN}\end{array}$ & $\begin{array}{l}700 \pm 118 \\
380 \pm 64\end{array}$ & $\begin{array}{l}407 \pm 60 \\
227 \pm 34 \cdot 2\end{array}$ & $\begin{array}{l}479 \pm 30 \\
268 \pm 42\end{array}$ \\
\hline$\frac{\left(B_{12}-C N\right)}{\left(B_{12}+C N\right)} \%$ & $58 \cdot 3 \pm 8 \cdot 8$ & $57 \cdot 6 \pm 5 \cdot 8$ & $56 \cdot 7 \pm 3 \cdot 8$ \\
\hline
\end{tabular}

Means in $\mathrm{pg} / \mathrm{ml}$, with numbers of patients and SEM.

patients with neurological disease and the miscellaneous controls, but $\mathrm{B}_{12}-\mathrm{CN}$ expressed as a percentage of total $\mathrm{B}_{12}\left(\mathrm{~B}_{12}+\mathrm{CN}\right)$ is the same in all groups.

\section{DISCUSSION}

Although ataxic tropical neuropathy, the degenerative neurological syndrome described in Nigerians and Tanzanians, is clinically similar in both countries, there is a dearth of post-mortem studies of the condition, and therefore conclusions about their identity must be tentative.

Nevertheless, the demonstration of high plasma thiocyanate concentrations in patients in both countries suggests that in both groups there is an excessive exposure to cyanide or cyanide precursors. Cassava is not yet as popular a food in Tanzania as in W. Africa but, in the absence of data for the prevalence of the disease in Tanzania, it is impossible to know at present whether or not the less extensive use of cassava is reflected in a lower frequency of the disease. The findings presented here support the hypothesis that there is a risk of developing a progressive neurological disease after chronic cyanide exposure. It is known that the detoxification of $\stackrel{\bar{O}}{\mathrm{O}}$ cyanide to thiocyanate requires a substrate of $z$ mercaptopyruvate or thiosulphate, both of $\stackrel{\oplus}{=}$ which are derived from sulphur-containing of amino acids that tend to be lacking in many tropical diets, and therefore protein malnu- 0 trition may also be a contributory factor. If so, the efforts to extend the use of cassava by agricultural advisers in developing countries $\underset{2}{2}$ should be accompanied by measures to improve the quality of the diet, as well as by the cultiva- $\stackrel{?}{?}$ tion of strains of cassava which produce much? smaller amounts of linamarin than present $\frac{\mathrm{o}}{\overline{\mathrm{N}}}$ popular varieties.

It has been suggested that extraction of $\stackrel{\mathbb{Q}}{\circ}$ vitamin $B_{12}$ from plasma with added cyanide के varies according to the exogenous exposure of $\vec{\circ}$ the donor to cyanide (Smith, 1961). Thus the $\overrightarrow{\vec{H}}$ proportion of vitamin $B_{12}$ obtained without the addition of cyanide to the extraction buffer $\left(\mathrm{B}_{12}-\mathrm{CN}\right)$ expressed as a percentage of vitamin $\mathrm{B}_{12}$ formed by extracting plasma with cyanide- $\omega$ containing buffer $\left(\mathrm{B}_{12}+\mathrm{CN}\right)$ is higher in smokero $\vec{\omega}$ than in non-smokers (Wilson and Matthew 1966). In the present study the significance of the serum vitamin $\mathbf{B}_{12}$ findings is not clear and the contrast with those of Monekosso and Wilsa 1 (1966). It is noteworthy, however, that in 8 separate Nigerian series (Osuntokun, 1969) an in a series of Europeans with Leber's disease whom a defect in cyanide metabolism has beent postulated (Wilson, Linnell, and Matthews, 1971) total serum vitamin $B_{12}$ concentrations were higher than in controls. Further study of this complex relationship is needed.

We acknowledge with gratitude the technical assistance of Miss June Quick and Mr. T. K. Basu.

\section{REFERENCES}

Aldridge, W. N. (1945). The estimation of micro quantities of cyanide and thiocyanate. Analyst, 70, 474-475.

Haddock, D. R. W., Ebrahim, G. J., and Kapur, B. B. (1962). Ataxic neurological syndrome found in Tanganyika. British Medical Journal, 2, 1442-1443.

Matthews, D. M. (1962). Observations on the estimation of serum vitamin $\mathrm{B}_{12}$ using Lactobacillus leichmannii. Clinical Science, 22, 101-111.

Monekosso, G. L., and Wilson, J. (1966). Plasma thiocyanate and vitamin $B_{12}$ in Nigerian patients with degenerative neurological disease. Lancet, 1, 1062-1064.

Osuntokun, B. O. (1968). An ataxic neuropathy in Nigeria. A clinical, biochemical, and electrophysiological study. O Brain, 91, 215-248.

Osuntokun, B. O. (1969). Chronic cyanide intoxication and a degenerative neuropathy in Nigeria. Ph.D. Thesis: University of Ibadan. 
Osuntokun, B. O., Durowoju, J. E., McFarlane, H., and Wilson, J. (1968). Plasma amino-acids in the Nigerian nutritional ataxic neuropathy. British Medical Journal, 3, 647-649.

Osuntokun, B. O., Monekosso, G. L., and Wilson, J. (1969). Relationship of a degenerative tropical neuropathy to diet. Report of a field survey. British Medical Journal, 1, 547550.
Smith, A. D. M. (1961). Retrobulbar neuritis in Addisonian pernicious anaemia. Lancet, 1, 1001-1002.

Wilson, J., Linnell, J. C., and Matthews, D. M. (1971). Plasma-cobalamins in neuro-ophthalmological diseases. Lancet, 1, 259-261.

Wilson, J., and Matthews, D. M. (1966). Metabolic interrelationships between cyanide, thiocyanate and vitamin $\mathbf{B}_{12}$ in smokers and non-smokers. Clinical Science, 31, 1-7. 